\title{
Soil pH as a Phenotype Determinant in Humans: Proposing a Scientific Hypothesis
}

\section{-Soil Phenotype}

\author{
Inderjit Kaur Barthakur* \\ Vasant Kunj, New Delhi, India \\ Email:*dtjyoti@gmail.com
}

How to cite this paper: Barthakur, I.K. (2018) Soil pH as a Phenotype Determinant in Humans: Proposing a Scientific Hypothesis. Open Journal of Soil Science, 8, 36-46.

https://doi.org/10.4236/ojss.2018.81003

Received: November 14, 2017

Accepted: January 13, 2018

Published: January 16, 2018

Copyright $\odot 2018$ by author and Scientific Research Publishing Inc. This work is licensed under the Creative Commons Attribution International License (CC BY 4.0).

http://creativecommons.org/licenses/by/4.0/ (c) (i) Open Access

\begin{abstract}
Plant growth, habitat of various microorganisms, sustenance conditions for the fauna and flora, are determined by the quality of soil. However, alteration in the properties of soil leads to various deficiencies/diseases in plants and thereby affects dependent fauna. The alkalinity and acidity of the soil refer to the change in $\mathrm{pH}$ value of the soil. In the North East India, most of the soils lack calcium $(\mathrm{Ca})$ and are acidic. Therefore, majority of the fauna and flora have lower availability of $\mathrm{Ca}$ due to leaching, caused by the heavy rainfall. The present study hypothesizes that the life originating from areas deficient in $\mathrm{Ca}$, impacts their bone concentration and facial formation. This makes them phenotypically distinct from their counterparts residing in the other regions which have alkaline soils or have the optimum $\mathrm{pH}$ value of soil. Strongly acidic soils, might have led to the formation of the major Mongolian Race in humans.
\end{abstract}

\section{Keywords}

Soils, Acidity, Ca deficiency, North East India, Phenotypic Variations

\section{Introduction}

A natural medium for the growth of plants on the immediate surface of the earth, comprising of unconsolidated mineral and organic matter, is referred to as soil. It supports the growth of plants by providing nutrition for photosynthesis through harboring different minerals and nutrients required for the fixation and reduction of atmospheric carbon dioxide [1]. Besides, its role in the plants growth, soil impacts the life, including humans, to a greater extent. It acts as an indirect source of nutrition for humans as it ensures the supply of nutrients to 
humans through the plants and their products consumed by them [2].

Among the various chemical properties of soil, (salinity, carbon to nitrogen ratio, cation exchange capacity, organic matter), $\mathrm{pH}$ is highly important for the normal growth of fauna and flora. Basically, $\mathrm{pH}$ is the measure of the acidity or alkalinity of a soil which is measured as the logarithmic scale which implies that a drop of 1-unit in $\mathrm{pH}$ is a 10-fold increase in acidity. Based on the measure of $\mathrm{pH}$, soil is categorized as neutral ( $\mathrm{pH} 7.0)$, acidic $(\mathrm{pH}<7.0)$ and alkaline $(\mathrm{pH}>7.0)$. This occurs due to $\mathrm{H}^{+}$exchange processes that involve vegetable soil solutions and soil minerals [3]. Since the optimum $\mathrm{pH}$ for the growth of plants is between 5.5 - 7.5, fluctuations in the $\mathrm{pH}$ directly or indirectly affects the availability of nutrients to the plants. Hence, it influences the people of the respective geographical area [4]. It has also been reported that alkaline soils are characterized by varying percentages of soluble salts, mainly chlorides and sulphates of the alkali bases, while the acidic soils lack in basic cations such as calcium (Ca), magnesium $(\mathrm{Mg})$, potassium $(\mathrm{K})$, sodium $(\mathrm{Na})$.

Acidic and alkaline soils are distributed throughout India [5] [6]. Acidic soils have $\mathrm{pH}$ lesser than 7.0. These soils are further categorized as slightly acidic ( $\mathrm{pH}$ range 6.6 to 6.1 ), medium acidic (pH 6.0 to 5.6), strongly acidic (pH 5.5 to 5.1), very strong acidic (with $\mathrm{pH} 5.0$ to 4.6 ) and extremely strong acidic (pH 4.5 to lower) [7].

In India, most areas of the North East (NE) states predominantly, have strongly acidic $\mathrm{pH}$ value of the soils. These regions, lying between $25.5736^{\circ} \mathrm{N}$, $93.2473^{\circ} \mathrm{E}$, also receive heavy rainfall (annual rainfall $1350 \mathrm{~mm}$ ) [8]. The heavy rainfall leaches away various minerals and cations such as $\mathrm{Ca}, \mathrm{Mg}$, $\mathrm{P}$, etc., hence rendering the soil acidic. This leads to leakage of these important minerals from the surface of soil, making them unavailable to the flora growing on such soils [8] [9]. The changes in environmental factors also influence the growth patterns in the flora, fauna and humans living there [10].

Many studies assessing the genetics behind the phenotype of a human being reported many genes to be responsible for governing the morphogenesis of facial structures. However, various studies determining the interactions between human genes and the environment have also established that the expression of genes of individuals are influenced by their surroundings/environment [7] [11]. The present study hypothesizes the effect of soil $\mathrm{pH} /$ soil constituency on the facial appearance of the people with the NE Indian origin or ancestral background. We have also focused on the type of soil found in NE India, emphasizing on its constituency and lack of nutrients, which basically governs the facial features of NE Indian population.

\section{Hypothesis}

The NE Region (NER) of India, spreading over $255,090 \mathrm{~km}^{2}$ (Figure 1), with $170,000 \mathrm{~km}^{2}$ under forest coverage, has a thin soil cover which is highly leached and is nutrient-deficient [12] [13]. The temperature found over this region 


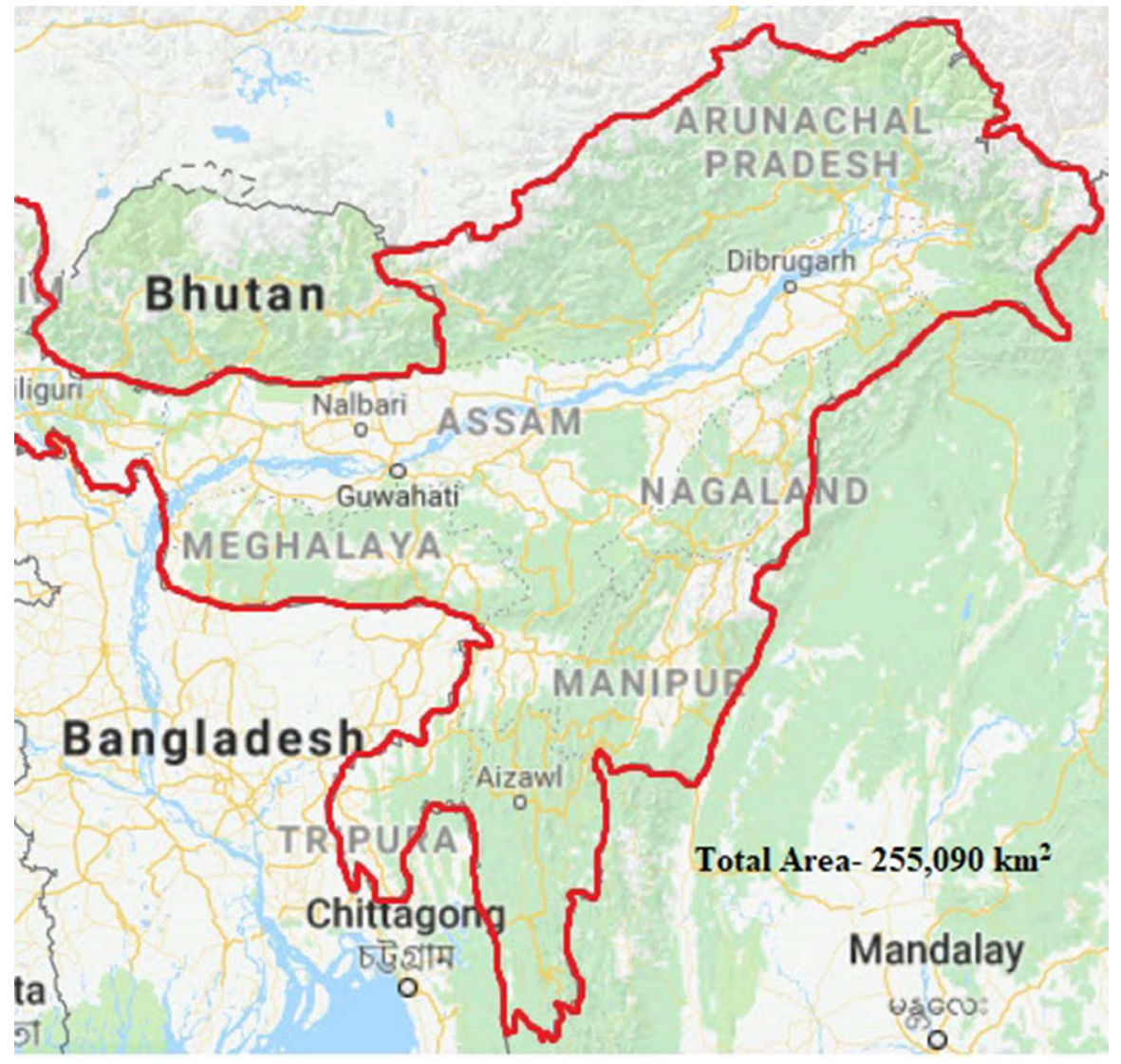

Figure 1. Geographical map representing the area under North East India region. http://theconversation.com/bridges-and-roads-in-north-east-india-may-drive-small-tribe s-away-from-development-78636 (Source).

varies between $21^{\circ} \mathrm{C}-31^{\circ} \mathrm{C}$ (high) and $12^{\circ} \mathrm{C}-20^{\circ} \mathrm{C}$ (low) [14]. As the annual rainfall in this geographical area is $10,372 \mathrm{~mm}$, leaching (loss of nutrients from the soil) is highly observed. It has been observed that leaching results in the loss of basic cations such as $\mathrm{Ca}, \mathrm{Mg}, \mathrm{K}$ and $\mathrm{Na}$ from the soil [8] [9]. The increased acidity of the soil leads to the biggest impediment associated with the crop productivity in NER [15] [16]. These factors get intensified under the rising atmospheric $\mathrm{CO}_{2}$, which might lead to more carbonic acid $\left(\mathrm{H}_{2} \mathrm{CO}_{3}\right)$ formation in soil water that removes base cations from the soil, by leaching, and hence, alleviating soil acidification in this region [17].

The people originating from the states of NE India are phenotypically different from other Indians. Moreover, people with an ancestral background/history associated with these states also possess the similar morphology [2]. We hypothesize that the facial features of the most of the human population with the NE Indian foundation or ancestral background are influenced by the soil constituency of that geographical area. Since the soil in this region is acidic (owing to leaching), an important element, i.e., Ca is deficient in the soil, thereby, it is not available to the humans in sufficient amount. $\mathrm{Ca}$, however, is necessary for human growth as it is the main constituent in the bone mineralization. Due to suboptimal intake of Ca, NE Indian people bear flatter faces. They have smaller 
noses and their nasal bridges are depressed with wider cheekbones. As compared to other Indians, their orbital fissures are smaller and slanted. Their incisor teeth are "shovel-shaped". Moreover, these people are shorter in height and have a flat occiput (back of the head). The study hypothesis is diagrammatically represented in Figure 2.

\section{Discussion}

Soil benefits humans through various ways such as by recycling the nutrients, maintaining the optimum cationic and anionic balance, sustaining biodiversity and habitat, conserving water level, ensures food availability and governs the interactions between humans and various chemicals and pathogens [2] [18].

Alkaline soils are found in Indian states of Uttar Pradesh, West Bengal, Punjab, Bihar, Orissa, Maharashtra, Tamil Nadu, Madhya Pradesh, Andhra Pradesh, Gujarat, Delhi and Rajasthan. Overall, these states cover an area of about 7 million hectares [19]. Plants growing on such soils are mostly stunted due to plasmolysis, i.e., loss of optimum amount of water from the cells. It may retard the germination of seeds and growth of seedlings. Chlorides cause death of plants even before bearing fruits. This further leads to reduced leaf size, superficial plant roots, brown or black stems, lesser developed green tissues [3] [20].

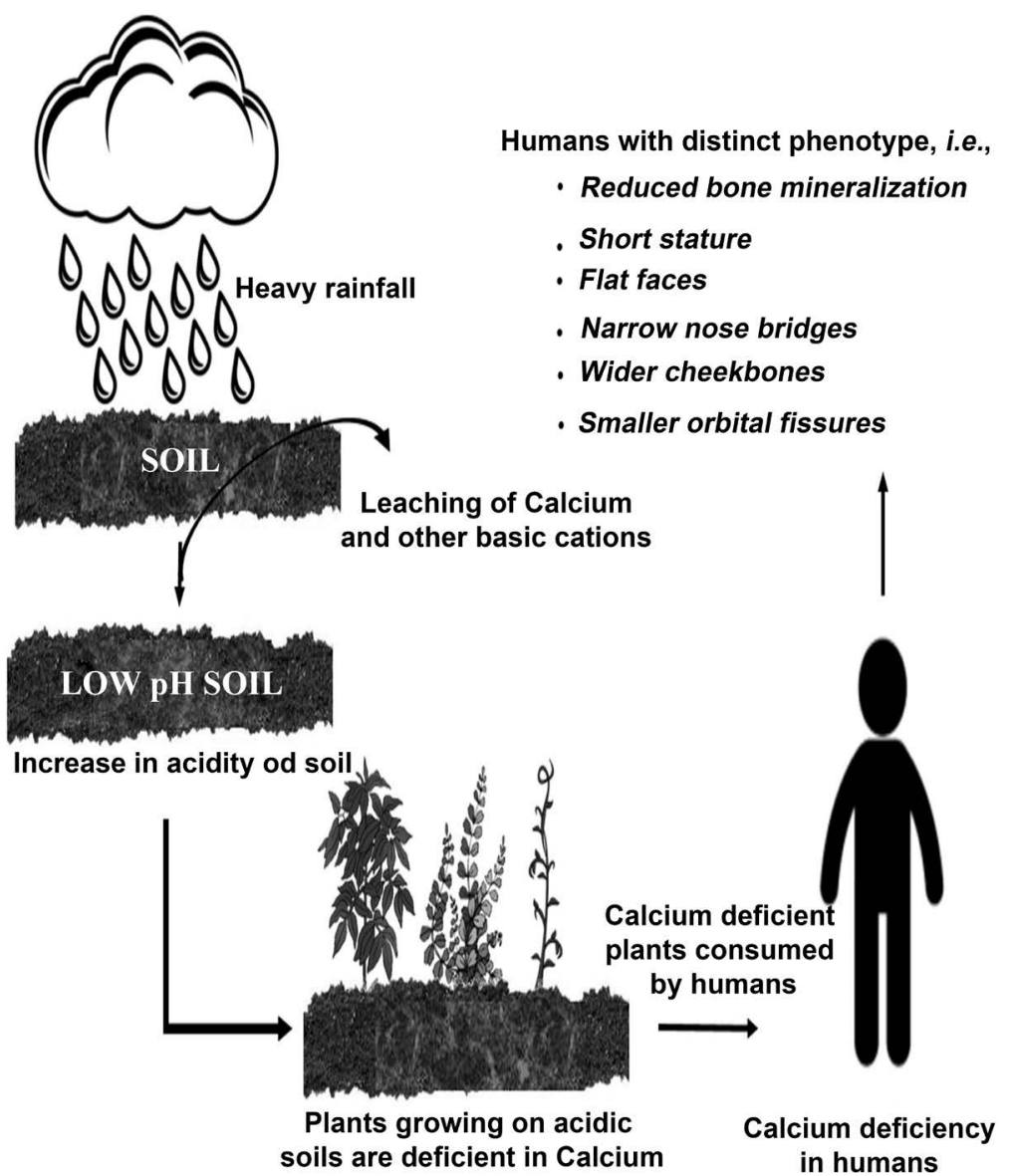

Figure 2. Diagrammatic representation of the study hypothesis. 
It has been observed that the acidic soils have $\mathrm{pH}$ value 5.0 or even less than that and receive more than $750 \mathrm{~mm}$ annual rainfall. Acidic soil is prominently found in the seven sister states of NE India viz., Assam, Meghalaya, Arunachal Pradesh, Mizoram, Nagaland, Manipur, Tripura and some areas of West Bengal and Bihar in India. All these states are humid and experience heavy rainfalls over the year (annual rainfall $1350 \mathrm{~mm}$ ) [8].

Besides heavy rainfall, the other factors leading to the acidity of soil are continuous removal of lime and other base elements by crops and accumulation of acids contained in the manures, application of acid forming fertilizers in the soil, microbial action, formation of soil on the acidic rocks [8] [17]. Toxic and deleterious effects on root tissues, reduced permeability of plasma membrane for cations, imbalanced basic and acid constituent levels and disturbed enzymatic processes are some of the direct effects posed by the acidic soils on the plant growth [21] [22].

Human races represent different groups of people that share certain visible physical characteristics (facial features, skin color, eyes formation, hair texture, etc.). Also referred to as subspecies, these races are differentiated at genetic level and are geographically confined. However, they may coexist at any given time [23] [24]. The three major human races across the world are Caucasoid race (populations of Europe, North Africa, the Horn of Africa, Western Asia, South Asia, Central Asia), Mongolian race (East Asia, Central Asia, Southeast Asia, Eastern Russia, Northern Europe, the Arctic, the Americas, parts of the Pacific Islands, parts of Africa (Madagascar) and parts of South Asia) and Ethiopian or Negroid race (populations in Sub-Saharan Africa) [25] [26].

Indian population belongs to the Mongoloid race. Although belonging to the same race, certain striking differences are still observed among the populations residing across the Indian states. People with NE Indian origin look distinct from Indians originating from the rest of the Indian states. Ecological, biological, geographical, racial, gender and age factors affect the variations among (inter-) and within (intra-) the population [27]. Craniofacial variability and body height are also affected by environmental factors such as diet, climate, and weather [5] [27]. It has been reported that the size of maxillary alveolar arch increases with the variations in the food habits [28]. In case of Mongolians, a greater variation in facial flatness has been observed [29] [30] [31].

People originating from Russia, a part of the Asian continent, and different regions of Europe survive on various soil types. Prominent among those found in Europe are Cambisols, Chernozems, Calcisols, Solonetz and Podzols, where Cambisols and Chernozems cover most of the land area viz., 26.72\% and 9.00\%, respectively [32]. Chernozems are predominantly found in Russia also [33]. Most of these soils are predominantly rich in Ca owing to characteristics such as low temperatures, low precipitation, impeded drainage, highly calcareous, high biological activity and weathering-resistant parent material are typical of these soils [21] [32]. Calcisols are rich in $\mathrm{Ca}$, present in the form of calcium carbonate, 
calcite and calcrete (soft or hard lime) or/and exchangeable calcium, are also found across Europe and Russia [34]. Since the soils found in Europe and Russia mostly contain high amount of $\mathrm{Ca}$, though in various forms, these have a moderately alkaline $\mathrm{pH}$.

Besides the features of the soils found in these countries, Russia receives moderate annual rainfall ranging between $200-750 \mathrm{~mm}$ [35]. While the majority of the countries of Europe continent have annual rainfall ranging between $300-800$ $\mathrm{mm}$, a few areas receive rainfall up to $4000 \mathrm{~mm}$ [36]. Though the rainfall is sufficient, it does not cause any leaching of minerals.

Both the factors, i.e., no leaching as well as Ca rich soils, lead to adequate amount of available $\mathrm{Ca}$ to the plants. Hence, the humans feeding on $\mathrm{Ca}$ rich plants get enough $\mathrm{Ca}$ to support mineralization of their bones. Therefore, Caucasoids (the human race found in Russia and the European continent) are influenced by the highly available $\mathrm{Ca}$ in their diet resulting in usually medium to tall stature with well-defined and sharpened facial features. The face is narrow, long and lacks protrusion of the jaws. The chin is pronounced and nose is sharp with a high nasal bridge [37] [38]. These features can be attributed to the composition of the soil found in the respective regions which are rich in $\mathrm{Ca}$ and are alkaline in nature.

The nutrient imbalance may be in the form of deficiency as well. The NE soils which are acidic and lacking sufficient $\mathrm{Ca}$ cause deficiency of $\mathrm{Ca}$ in humans due to the consumption of Ca-deficient plants growing on such soils. Insufficient $\mathrm{Ca}$ levels in the soils cause deterioration of cell membranes leading to leakage and thus, loss of cell components. Ca acts as a messenger in the regulation of nutrition uptake processes and other metabolic processes occurring in the plants [3] [39] [40]. It protects plant cells against the attacks by microbes. More the calcium concentration in the cells, higher are the pectin amounts holding the cells firmly against each other and hence resisting the invading by microbes [3].

In humans, $\mathrm{Ca}$ is the most important mineral that forms the basis of bone mineralization. Its deficiency in the human diet (due to intake of Ca deficient plants) leads to many deficiencies such as low bone composition and dimensions, high incidence of dental caries, rickets, osteomalacia and osteoporosis, and defective non-skeletal processes [6]. A study by Dibba and co-workers has even established poor growth performance and bone mineralization in Ca deficient people [41] [42]. Its deficiency also leads to an impaired growth and delay in consolidation of the skeleton [41]. Such a reduction in the bone mineralization and concentration causes flat facial features, shorter bones and shorter heights in the NE Indian population due to lesser deposition of minerals in the bones [28] [43] [44]. The current hypothesis is further supported by the fact that the women with vitamin D deficiency and consuming insufficient $\mathrm{Ca}$ might have lower calcium secretion in their breast milk [45]. The effect of low calcium availability has also been seen on the fauna of the NER. According to the Indian Dairy Industry report, the production of milk in dairy industry shows variance 
among the different regions in India. The per capita availability (in grams) of milk in the north, west, south and east are 278, 174, 148 and 93, respectively [43].

It is believed that the genetics of an individual decide the phenotype. However, various genetic studies provide evidences to support the current hypothesis. Different genes express themselves and are responsible for specific physical appearance of an individual. In different studies by Ahlgren and co-workers (1999), Hu et al (2003) and Brito and co-workers (2006, 2008), genes namely, FEZ (frontal ectodermal zone) and Shh (Sonic hedgehog) govern the morphogenesis of facial structures [7] [11] [20]. In the study by Ahlgren et al, 1999, the inhibition of Shh gene signaling using hybridoma cells led to a significant reduction in the head size and was even responsible for facial and forebrain abnormalities [7]. In these studies on chick embryos, it was observed that inhibition of signaling of FEZ and Shh genes resulted in smaller head crest, brachial arch loss, and smaller jaw size [7] [11].

However, various studies on interactions between human genes and the environment have established that the expression of genes of individuals are influenced by their environment [46] [47]. Disease causing genes, regulatory genes, genes controlling the development of a living being, all express in association with the environmental factors (lifestyle habits, mineral and nutrient deficiencies, prescribed and non-prescribed drug intake) [46] [47] [48] [49] [50]. One such environmental factor is the nutrient imbalance which may govern the physical appearance of a person. The nature of soils and the rainfall patterns in different regions of the world can regulate the specific physical features among the same and the different human races.

\section{Conclusion}

Overall, the deficiency of $\mathrm{Ca}$ in the diet of the NE Indians occurs due to the acidic nature of the NE Indian soil which lacks $\mathrm{Ca}$. An insufficient amount of $\mathrm{Ca}$ in the diet leads to reduced bone mineralization in humans which results in their distinct phenotypic appearance, as of the Mongolian race. The other two major human races of the world might also get the explanations in some other soil variables.

\section{Acknowledgements}

The author acknowledges her relatives, friends and Miss Krishna Tokas for their moral support and motivating her to pen down the proposed hypothesis. The author also acknowledges Knowledge Isotopes Pvt. Ltd. for their assistance in writing the review.

\section{Funding}

This research did not receive any specific grant from funding agencies in the public, commercial, or not-for-profit sectors. 


\section{Conflict of Interest}

The research was conducted in the absence of any commercial or financial relationships that could be construed as a potential conflict of interest.

\section{References}

[1] Retallack, G. (2003) Soils and Global Change in the Carbon Cycle over Geological Time. Treatise on Geochemistry, 5, 581-605.

http://adsabs.harvard.edu/abs/2003TrGeo...5..581R https://doi.org/10.1016/B0-08-043751-6/05087-8

[2] Brevik, E.C. and Sauer, T.J. (2015) The Past, Present, and Future of Soils and Human Health Studies. Soil, 1, 35-46. https://doi.org/10.5194/soil-1-35-2015

[3] van Breemen, N., Mulder, J. and Driscoll, C. (1983) Acidification and Alkalinization of Soils. Plant and Soil, 75, 283-308. https://doi.org/10.1007/BF02369968

[4] Barrere, F., van Blitterswijk, C.A. and de Groot, K. (2006) Bone Regeneration: Molecular and Cellular Interactions with Calcium Phosphate Ceramics. International Journal of Nanomedicine, 1, 317-332.

[5] Baruah, T., Mondal, S., Gharami, A.K. and Adak, D.K. (2006) The Tai-Phake of Assam, India-A Morphometric Study and Population Comparison with Neighbouring Groups. Collegium Antropologicum, 30, 579-583.

[6] Walker, A.R. (1972) The Human Requirement of Calcium: Should Low Intakes Be Supplemented? American Journal of Clinical Nutrition, 25, 518-530.

[7] Ahlgren, S.C. and Bronner-Fraser, M. (1999) Inhibition of Sonic Hedgehog Signaling in vivo Results in Craniofacial Neural Crest Cell Death. Current Biology, 9, 1304-1314. https://doi.org/10.1016/S0960-9822(00)80052-4

[8] Lc, P.S.B., As, D., H.M., Rh, T. and Ks, S. (2013) Facial Indices of North and South Indian Adults: Reliability in Stature Estimation and Sexual Dimorphism. Journal of Clinical and Diagnostic Research, 7, 1540-1542.

https://doi.org/10.7860/JCDR/2013/5497.3204

[9] Lehmann, J. and Schroth, G. (2003) Nutrient Leaching. In: Schroth, G., Sinclair, F., Eds., Trees, Crops and Soil Fertility, CABI Publishing, Wallingford, 151-166.

[10] Bashey, F. (2006) Cross-Generational Environmental Effects and the Evolution of Offspring Size in the Trinidadian Guppy Poecilia reticulata. Evolution, 60, 348-361. https://doi.org/10.1111/j.0014-3820.2006.tb01111.x

[11] Brito, J.M., Teillet, M.-A. and Le Douarin, N.M. (2006) An Early Role for Sonic Hedgehog from Foregut Endoderm in Jaw Development: Ensuring Neural Crest Cell Survival. Proceedings of the National Academy of Sciences, 103, 11607-11612. https://doi.org/10.1073/pnas.0604751103

[12] Sharma, U.C. and Prasad, R.N. (1995) Socio-Economic Aspects of Acid Soil Management and Alternative Landuse Systems for North Eastern States of India. In: Date, R.A., Grundon, N.J., Rayment, G.E. and Probert, M.E., Eds., Plant-Soil Interactions at Low pH: Principles and Management, Kluwer Academic Press, The Netherlands, 689-695.

[13] Dikshit, K. and Dikshit, J.K. (2014) Natural Vegetation: Forests and Grasslands of North-East India. North-East India: Land, People and Economy, Springer, 213-255.

[14] Current Results (2017) Average Annual Temperatures in India https://www.currentresults.com/Weather/India/average-annual-temperatures.php.

[15] Khiewtam, R. and Ramakrishnan, P. (1993) Litter and Fine Root Dynamics of a Re- 
lict Sacred Grove Forest at Cherrapunji in North-Eastern India. Forest Ecology and Management, 60, 327-344. https://doi.org/10.1016/0378-1127(93)90087-4

[16] Kumar, M. (2011) North East India: Soil and Water Management Imperatives for Food Security in a Changing Climate. Current Science, 101, 1119.

[17] Kumar, M. (2011) Evidences, Projections and Potential Impacts of Climate Change on Food Production in Northeast India. Indian Journal of Hill Farming, 24, 1-10.

[18] Bot, A. and Benites, J. (2005) The Importance of Soil Organic Matter: Key to Drought-Resistant Soil and Sustained Food Production: Food \& Agriculture Org.

[19] Choudhary, O., Ghuman, B., Dhaliwal, M. and Chawla, N. (2010) Yield and Quality of Two Tomato (Solanum lycopersicum L.) Cultivars as Influenced by Drip and Furrow Irrigation using Waters Having High Residual Sodium Carbonate. Irrigation Science, 28, 513-523. https://doi.org/10.1007/s00271-010-0211-y

[20] Hu, D., Marcucio, R.S. and Helms, J.A. (2003) A Zone of Frontonasal Ectoderm Regulates Patterning and Growth in the Face. Development, 130, 1749-1758. https://doi.org/10.1242/dev.00397

[21] Delhaize, E. and Ryan, P.R. (1995) Aluminum Toxicity and Tolerance in Plants. Plant Physiology, 107, 315-321. https://doi.org/10.1104/pp.107.2.315

[22] Driscoll, C.T., Lawrence, G.B., Bulger, A.J., Butler, T.J., Cronan, C.S., Eagar, C., Lambert, K.F., Likens, G.E., Stoddard, J.L. and Weathers, K.C. (2001) Acidic Deposition in the Northeastern United States: Sources and Inputs, Ecosystem Effects, and Management Strategies. BioScience, 51, 180-198. https://doi.org/10.1641/0006-3568(2001)051[0180:ADITNU]2.0.CO;2

[23] Patterson G. Calcium Nutrition in Plants. http://www.alcanada.com/index_htm_files/Calcium\%20Nutrition\%20in\%20Plants. pdf

[24] Templeton, A.R. (1998) Human Races: A Genetic and Evolutionary Perspective. American Anthropologist, 100, 632-650. https://doi.org/10.1525/aa.1998.100.3.632

[25] Carleton, S.C. (1939) The Races of Europe. Macmillan Publishers, London.

[26] Molnar, S. (2006) Human Variation: Races, Types, and Ethnic Groups. Pearson Prentice Hall, Upper Saddle River.

[27] Durtschi, R.B., Chung, D., Gentry, L.R., Chung, M.K. and Vorperian, H.K. (2009) Developmental Craniofacial Anthropometry: Assessment of Race Effects. Clinical Anatomy, 22, 800-808. https://doi.org/10.1002/ca.20852

[28] Prasanna, L., Bhosale, S., D’souza, A., Mamatha, H., Thomas, R. and Sachin, K. (2013) Facial Indices of North and South Indian Adults: Reliability in Stature Estimation and Sexual Dimorphism. Journal of Clinical and Diagnostic Research: JCDR, 7, 1540-1542.

[29] Ishida, H. (1992) Flatness of Facial Skeletons in Siberian and Other Circum-Pacific Populations. Zeitschrift Fur Morphologie Und Anthropologie, 79, 53-67.

[30] Ishida, H. and Dodo, Y. (1997) Cranial Variation in Prehistoric Human Skeletal Remains from the Marianas. American Journal of Physical Anthropology, 104, 399-410. https://doi.org/10.1002/(SICI)1096-8644(199711)104:3<399::AID-AJPA9>3.0.CO;2-Q

[31] Ishida, H., Uesugi, T., Hirai, K., Toda, T., Nukaya, H., Yokotsuka, K. and Tsuji, K. (1998) Preventive Effects of the Plant Isoflavones, Daidzin and Genistin, on Bone Loss in Ovariectomized Rats Fed a Calcium-Deficient Diet. Biological and Pharmaceutical Bulletin, 21, 62-66. https://doi.org/10.1248/bpb.21.62 
[32] DeHayes, D.H., Schaberg, P.G., Hawley, G.J. and Strimbeck, G.R. (1999) Acid Rain Impacts on Calcium Nutrition and Forest Health Alteration of Membrane-Associated Calcium Leads to Membrane Destabilization and Foliar Injury in Red Spruce. BioScience, 49, 789-800. https://doi.org/10.2307/1313570

[33] Lapenis, A., Lawrence, G., Bailey, S., Aparin, B., Shiklomanov, A., Speranskaya, N., Torn, M. and Calef, M. (2008) Climatically Driven Loss of Calcium in Steppe Soil as a Sink for Atmospheric Carbon. Global Biogeochemical Cycles, 22, GB2010. https://doi.org/10.1029/2007GB003077

[34] Tóth, G., Montanarella, L., Stolbovoy, V., Máté, F., Bódis, K., Jones, A., Panagos, P. and Van Liedekerke, M. (2008) Soils of the European Union. JRC Scientific and Technical Reports, Office for Official Publications of the European Communities, Luxembourg.

[35] Weather Online. Russia. http://www.weatheronline.co.uk/reports/climate/Russia.htm

[36] Chan, G.M., McElligott, K., McNaught, T. and Gill, G. (2006) Effects of Dietary Calcium Intervention on Adolescent Mothers and Newborns: A Randomized Controlled Trial. Obstetrics \& Gynecology, 108, 565-571. https://doi.org/10.1097/01.AOG.0000231721.42823.9e

[37] Riggs, K.S., Syers, J.K., Rimmer, D.L. and Sumner, M. (1995) Effect of Liming on Calcium and Magnesium Concentrations in Herbage. Journal of the Science of Food and Agriculture, 69, 169-174. https://doi.org/10.1002/jsfa.2740690206

[38] Shortle, W.C. and Smith, K.T. (1988) Aluminum-Induced Calcium Deficiency Syndrome in Declining Red Spruce. Science, 240, 1017-1018. https://doi.org/10.1126/science.240.4855.1017

[39] Cote, G.G. and Crain, R.C. (1993) Biochemistry of Phosphoinositides. Annual Review of Plant Biology, 44, 333-356. https://doi.org/10.1146/annurev.pp.44.060193.002001

[40] Kauss, H. (1987) Some Aspects of Calcium-Dependent Regulation in Plant Metabolism. Annual Review of Plant Physiologyogy, 38, 47-71. https://doi.org/10.1146/annurev.pp.38.060187.000403

[41] Pravina, P., Sayaji, D. and Avinash, M. (2013) Calcium and Its Role in Human Body. International Journal of Research in Pharmaceutical and Biomedical Sciences, 4, 659-668.

[42] Johnston Jr, C.C., Miller, J.Z., Slemenda, C.W., Reister, T.K., Hui, S., Christian, J.C. and Peacock, M. (1992) Calcium Supplementation and Increases in Bone Mineral Density in Children. New England Journal of Medicine, 327, 82-87. https://doi.org/10.1056/NEJM199207093270204

[43] Hanihara, T. (2000) Frontal and Facial Flatness of Major Human Populations. American Journal of Physical Anthropology, 111, 105-134. https://doi.org/10.1002/(SICI)1096-8644(200001)111:1<105::AID-AJPA7>3.0.CO;2$\underline{\mathrm{O}}$

[44] Hirschi, K.D. (2004) The Calcium Conundrum. Both Versatile Nutrient and Specific Signal. Plant Physiology, 136, 2438-2442. https://doi.org/10.1104/pp.104.046490

[45] Alloway, B.J. (2009) Soil Factors Associated with Zinc Deficiency in Crops and Humans. Environmental Geochemistry and Health, 31, 537-548. https://doi.org/10.1007/s10653-009-9255-4

[46] Bateson, P., Barker, D., Clutton-Brock, T., Deb, D., D’Udine, B., Foley, R.A., Gluckman, P., Godfrey, K., Kirkwood, T. and Lahr, M.M. (2004) Developmental 
Plasticity and Human Health. Nature, 430, 419-421.

https://doi.org/10.1038/nature02725

[47] Plomin, R., DeFries, J.C. and Loehlin, J.C. (1977) Genotype-Environment Interaction and Correlation in the Analysis of Human Behavior. Psychological Bulletin, 84, 309-322. https://doi.org/10.1037/0033-2909.84.2.309

[48] Hunter, D.J. (2005) Gene-Environment Interactions in Human Diseases. Nature Reviews Genetics, 6, 287-298. https://doi.org/10.1038/nrg1578

[49] Murray, J.C. (1995) Face Facts: Genes, Environment, and Clefts. The American Journal of Human Genetics, 57, 227-232.

[50] Brito, J.M., Teillet, M.A. and Le Douarin, N.M. (2008) Induction of Mirror-Image Supernumerary Jaws in Chicken Mandibular Mesenchyme by Sonic Hedgehog-Producing Cells. Development, 135, 2311-2319.

https://doi.org/10.1242/dev.019125 